IZA DP No. 4350

Immigrant Self-Employment:

Does Intermarriage Matter?

Dimitris Georgarakos

Konstantinos Tatsiramos

August 2009 


\title{
Immigrant Self-Employment: Does Intermarriage Matter?
}

\author{
Dimitris Georgarakos \\ Goethe University Frankfurt and CFS \\ Konstantinos Tatsiramos \\ $I Z A$
}

Discussion Paper No. 4350

August 2009

IZA

P.O. Box 7240

53072 Bonn

Germany

Phone: +49-228-3894-0

Fax: +49-228-3894-180

E-mail: iza@iza.org

\begin{abstract}
Any opinions expressed here are those of the author(s) and not those of IZA. Research published in this series may include views on policy, but the institute itself takes no institutional policy positions.

The Institute for the Study of Labor (IZA) in Bonn is a local and virtual international research center and a place of communication between science, politics and business. IZA is an independent nonprofit organization supported by Deutsche Post Foundation. The center is associated with the University of Bonn and offers a stimulating research environment through its international network, workshops and conferences, data service, project support, research visits and doctoral program. IZA engages in (i) original and internationally competitive research in all fields of labor economics, (ii) development of policy concepts, and (iii) dissemination of research results and concepts to the interested public.
\end{abstract}

IZA Discussion Papers often represent preliminary work and are circulated to encourage discussion. Citation of such a paper should account for its provisional character. A revised version may be available directly from the author. 


\begin{abstract}

\section{Immigrant Self-Employment: Does Intermarriage Matter?*}

This paper investigates the effect of a native spouse on the transitions into and out of entrepreneurship of male immigrants in the U.S. We find that those married to a native are less likely to start up a business compared to those married to an immigrant. This finding is robust when the endogeneity of being married to a native is taken into account. We also show that immigrants married to a native are significantly less likely to exit from entrepreneurship compared to their counterparts who are married to an immigrant. Our results point to an interesting asymmetric role of being intermarried in deciding to become an entrepreneur and for survival in entrepreneurship, which is consistent with a network effect. On the one hand, intermarriage reduces the chance of starting up a business possibly because better access to local networks can help transitions into other forms of employment (e.g. paid employment). On the other hand, superior access to local networks through marriage to a native spouse facilitates business survival.
\end{abstract}

JEL Classification: J12, J15, J61

Keywords: business ownership, migration, native spouse, social networks

Corresponding author:

Konstantinos Tatsiramos

IZA

P.O. Box 7240

53072 Bonn

Germany

E-mail: tatsiramos@iza.org

\footnotetext{
* The authors would like to thank two anonymous referees, Barry Chiswick, Bob Gregory and Jan van Ours for many useful comments. All errors remain our own. Dimitris Georgarakos acknowledges partial financial support from the Center for Financial Studies under the Research Program 'Household Wealth Management'. Konstantinos Tatsiramos acknowledges from the Volkswagen Foundation for the IZA project on "The Economics and Persistence of Migrant Ethnicity".
} 


\section{Introduction}

Employment opportunities for immigrants are very important for their economic integration and assimilation in the host country. The mechanism through which immigrants acquire information about existing employment opportunities and their access to local networks can determine their employment choices and well-being to a great extent. The aim of this paper is to investigate the effect of being married to a native - as a measure of association with natives - on the transitions in and out of entrepreneurship of male immigrants in the U.S. Immigrants married to a native can be considered as having access to a different network - other things equal - compared to their counterparts who are married to an immigrant.

Information acquired through networks can affect job search and employment opportunities (Calvó Armengol 2004, Calvó Armengol and Jackson 2007). Previous empirical literature has established that networks such as those developed through contacts with friends, relatives and people with similar characteristics are important in determining employment outcomes (Ioannides and Datcher Loury 2004, Munshi 2003, Beaman 2008). Networks have been also found to affect employed and unemployed workers in terms of both frequency of job offers and acceptance (Blau and Robins 1990). Recently, Patel and Vella (2007) provide evidence on the association between the occupational choices of newly arrived immigrants with those made by established immigrants of the same origin.

The main contribution of this paper is that we provide insights on how access to different types of networks through a native or immigrant spouse - among otherwise similar immigrants - can influence transitions into and out of entrepreneurship. ${ }^{1}$ In particular, married to a native can facilitate access to information provided by natives

\footnotetext{
${ }^{1}$ We use the term 'entrepreneurship' interchangeably with the terms 'self-employment' and 'business ownership.' Information on the latter is directly available in our data.
} 
and can ease job search. On the other hand, those who are married to another immigrant are more likely to develop closer links to their co-ethnic group in the state and become affected by practices that are common to the members of this group. For example, living in a state where a significant number of co-ethnic households run their own businesses may help newly arrived immigrants from the same origin to start up a business. ${ }^{2,3}$

The opportunity to set up a business can be very important for migrant welfare and particularly so among the less well-to-do. Self-employment rates across racial and ethnic groups differ substantially in the U.S., where Hispanics and African-Americans exhibit lower rates compared to Whites and Asians (Fairlie and Meyer 1996), and they perform worse in terms of earnings (Fairlie, 2005). Recent evidence also shows that many immigrants use self-employment as a pathway from unemployment or inactivity to paid employment in the wage sector, and this accounts for a significant part of the positive immigrant-native difference in exit rates from self-employment (Georgarakos and Tatsiramos, 2009). Considering transitions in and out of entrepreneurship is, therefore, important for our understanding of labor market transitions and selfemployment dynamics and is likely to shed more light on the role of different networks accessed by immigrants. This analysis can have implications for policies that target entrepreneurs from disadvantaged groups and aim to assist the assimilation of immigrants in the host country.

The current paper is related to a growing literature on the role of intermarriage on economic outcomes of immigrants. For instance, Meng and Gregory (2005) show that intermarriage leads to higher wages for non-English speaking immigrants in

\footnotetext{
2 The mechanism can be similar to the one suggested by Patel and Vella (2007) on occupational choice; the usefulness of information that longer stayed immigrants in a country can provide to their recently arrived co-ethnics has been emphasized by Beaman (2008).

${ }^{3}$ The empirical literature on the effect of ethnic concentration on economic outcomes is ambiguous. Edin et al. (2003) provide evidence that residence in ethnic enclaves improves the economic outcomes of immigrants; while Borjas (1995) finds that a higher share of co-ethnics slows earnings assimilation of immigrants' children, although higher skilled immigrants can benefit from a significant share of coethnics in the state (see also Cutler et al. 2008).
} 
Australia. In a recent study, Furtado and Theodoropoulos (2009) find that marriage to a native is associated with higher immigrant employment rates in the U.S.

We use panel data from the US Survey of Income and Program Participation (SIPP) for the years 1996 to 2004, which provides information on various socioeconomic characteristics on a monthly basis and offers details on immigrant status. We find evidence that being married to a native has asymmetric effects for transitions in and out of entrepreneurship. On the one hand, immigrants who have a native spouse are significantly less likely to enter into self-employment compared to those married to an immigrant. This finding is not driven by the possibility that unobserved factors affect both the probability of starting up a business and being intermarried, since our estimates are proven robust when such a source of endogeneity is taken into account. On the other hand, among immigrants who run their own business, those who are married to a native are significantly less likely to exit from entrepreneurship compared to their counterparts married to an immigrant. These results suggest that access to different networks and to different information acquired through them can affect the employment choices of immigrants. Moreover, the findings that immigrants married to other immigrants are not only more likely to start up a business but are also more likely to exit from that business, suggest the use of self-employment as a pathway to other forms of employment in the presence of limited access to information that could ease job search.

The rest of the paper is organized as follows. Details of the data are discussed in Section 2. Section 3 presents the empirical results for the transitions in and out of entrepreneurship. It also discusses the endogeneity issue and how this is treated by our estimation. Section 4 offers concluding remarks. 


\section{Data}

The empirical analysis is based on the 1996 and 2001 panels of the SIPP. The survey is a rotating panel collected every four months spanning over a 4 year and 3 year period in the 1996 and 2001 panels, respectively. Each wave of the SIPP contains both core questions common to all waves and topical questions that are not updated in each and every wave. The core questions provide direct information on whether each person in the household older than 16 owns a business or not. SIPP data also provide information on wealth holdings at the household level. From the assets and liabilities module, we derive a measure of total net wealth, which is equal to the value of total assets minus liabilities outstanding. Although the SIPP contains detailed information on specific assets and debts, it does not gather information about assets held off-shore, which may be particularly important for immigrant households. However, this is a limitation shared by all other available data sources, such as the PSID (see the discussion in Cobb-Clark and Hildebrand, 2006).

A key advantage of using the SIPP is that it includes a migration module in wave 2 of the panel. In the analysis, therefore, we focus on individuals who entered the sample in the first wave of 1996 and $2001{ }^{4}$ We are able to distinguish foreign-born individuals based on information about the country of birth in the migration module. Considering the foreign-born married individuals and given that the country of birth of the spouse is known, we can identify married couples who are both immigrants versus couples in which one is native-born. We consider only males of working age 20 to 64 years in order to avoid the selectivity issues related to female employment. The main

\footnotetext{
${ }^{4}$ The remaining sample represents about $90 \%$ of the total sample. We also exclude individuals born in Puerto Rico from the analysis on the basis that their unique legal position makes it difficult to sensibly include them in the foreign-born population, and American Indians, as they differ from the Americans and are too few to be included in the analysis as a separate group.
} 
variable of interest is a dummy indicator which equals one if the man is married to a native and zero otherwise. ${ }^{5}$

We employ two samples in the analysis: one for the decision to enter into entrepreneurship and the other for the decision to exit from entrepreneurship. The first sample consists of all those individuals who do not own a business during a given wave (quarter of a year), and so they are at risk of starting up a business in the subsequent wave. The dependent variable takes the value one if individuals enter into entrepreneurship in the subsequent quarter and zero otherwise. The second sample used to model exits consists of those individuals who are currently business owners. The dependent variable takes the value one if individuals exit from entrepreneurship and zero otherwise.

Summary statistics with reference to characteristics of the samples used to model entry into and exit from entrepreneurship are summarized by Tables 1 and 2 respectively. All descriptive statistics have been calculated using sample weights. The former sample consists of 1,528 individuals of which 324 are married to a native. The sample employed to model exit from entrepreneurship is significantly smaller and consists of 324 individuals who run their own business, of which 65 are intermarried. According to the descriptive information from both samples, intermarried immigrants are on average more educated and have a lower number of children compared to their counterparts with a foreign-born spouse. Notably, the median wealth and income of intermarried immigrants are significantly higher.

Tables 1 and 2 also present the regions of origin in each sample. We distinguish between 6 regions (Europe, Central America, South American, the Caribbean, Asia and Australia-New Zealand) and 2 countries (Mexico and Canada).

\footnotetext{
${ }^{5}$ For a detailed analysis of the determinants of ethnic intermarriage among immigrants, see Chiswick and Houseworth (2008).
} 
[Table 1 about here]

[Table 2 about here]

\section{Empirical Results}

In Section 3.1, we first examine the probability of entering into entrepreneurship among those who are not currently business owners. We also estimate a joint model of business entry and the probability of being intermarried (Section 3.2) in order to take into account the possibility that unobserved factors affect both decisions. Finally, we investigate the transitions out of business ownership in Section 3.3.

\subsection{Transitions into Entrepreneurship}

In this part, our aim is to assess empirically the influence of being married to a native in the transitions into entrepreneurship. To this end, we estimate a logit model on the probability of becoming a business owner in the subsequent wave among those who currently do not own a business, i.e. those who are unemployed, inactive or employed in the wage sector. Given that we observe individuals over time, the total number of observations corresponds to the pooled individual spells of non-business ownership. For each spell, the dependent variable denotes whether the individual entered into business in the subsequent wave. Our specification controls for various demographic and pecuniary characteristics. We account for age through a second order polynomial. To capture differences due to educational attainment, we include dummies distinguishing among college graduates, those with some college education, high school graduates, and those with less than high school education (which form the omitted category). In addition, we take into account the number of children and whether the individual resides 
in an urban area. We also control for resources by conditioning on total household income and wealth.

Given that we examine transitions into entrepreneurship, we control for the share of unemployed in the region to take into account the regional variation in employment opportunities. To gain an insight into the relative importance of the pre-transition status of each individual, we include dummies representing those previously unemployment or inactive. Those previously in paid employment form the reference group.

We take into account the years since immigration given that immigrants who have stayed longer may have better chances starting up a business. In addition, we include dummies controlling for naturalization given that it may influence the selfemployment opportunities of intermarried individuals, and for individuals who originally come from English speaking countries and thus have language proficiency. We also condition on the share of migrants in the state. This might partly reflect immigrant network effects in a given state. For example, in states where immigrants account for a non-trivial share of the local population, information sharing within a given immigrant group can be more efficient. Our key variable of interest is a dummy distinguishing immigrants who are married to an immigrant from those who are married to a native (intermarried). As has been already discussed, this can imply access to different types of networks (i.e. networks that are dominated by natives or by immigrants) and to different forms of information.

Results are presented on the left panel of Table 3, column 1. Differences in education and wealth do not suggest a significant influence. Yet higher income, after controlling for the pre-transition employment status, is negatively associated with a transition into self-employment. This might be due to the fact that entrepreneurship represents a way of avoiding poverty for the less well-to-do. Consistent with this notion, 
we also find that transitions into entrepreneurship are more likely for those previously unemployed or inactive compared to their counterparts in paid employment.

\section{[Table 3 about here]}

We estimate a strong negative effect of being intermarried on the probability of starting up a business that is net of the years since immigration. This suggests that there is heterogeneity among immigrants on their employment choices which depends on the nativity of their spouse. Being married to a native is likely to enhance information sharing and to facilitate easier access to the local networks dominated by natives. This can ease job search and increase the probability of finding a job in the wage sector. Our finding of a lower transition of intermarried immigrants into entrepreneurship is also consistent with recent evidence showing that many immigrants use entrepreneurship as a stepping stone to enter into paid employment (see Georgarakos and Tatsiramos, 2009). Being married to a native can make the choice of running a business as a transition state towards paid employment less probable by offering more opportunities to enter the wage sector directly.

Yet additional considerations might be at work. For example, immigrants who have assimilated better and gained more skills in the host country may be more likely to marry a native. In such a case, unobserved characteristics in our model correlate with both the choice to start up a business and the decision to marry a native, resulting into inconsistent estimates. In Section 3.2, we probe further into such an endogeneity issue by estimating jointly the probability for each incidence while allowing for unobserved factors to influence the two choices.

One might argue that in our baseline specification, while we control for years since migration, we do not take into account the possibility that some of the immigrants 
in our sample were already married when they arrived in the country. We check the robustness of our findings against this concern in the following ways.

First, we estimate our baseline model for immigrants who arrived at different ages in the country. Results are presented in Table 3, columns 2 and 3. Immigrants younger than 20 years old when first coming to the US are less likely to have married before their arrival and are consequently more likely to marry a native. On the other hand, when immigrants who arrived at a later age are included in the sample, the share of those more likely to have married prior to their arrival should then increase. We still derive a strong negative effect of being intermarried, and the rest of our results remain essentially unaffected when we estimate our model over these two different samples of immigrants.

Second, we estimate the same model of transitions into entrepreneurship among those who married after migration. Results are presented in the right panel of Table 3, column 4. The estimates of the dummy representing those who are intermarried remain unaffected, providing further support to our baseline findings.

\subsection{Endogeneity}

In this section, we address the endogeneity issue that arises from the possibility that immigrants' unobserved characteristics contribute both to the likelihood of starting up a business and the probability of being married to a native. Given the discrete nature of both decisions, we estimate a two equation model by maximum likelihood while allowing for individual-specific and time-invariant unobserved characteristics to affect each decision. The probability of entering self-employment is defined as:

$$
P_{S E}=\operatorname{Pr}\left(S E=1 \mid X_{i}, \varepsilon_{i}\right)=\Lambda\left(y^{S E}\right),
$$


where the index is $y^{S E}=\beta_{0}^{S E}+\beta_{1} I M+\beta_{2}^{S E} X_{i}+\varepsilon_{i}^{S E}$, and the probability of being intermarried is defined as:

$$
P_{I M}=\operatorname{Pr}\left(I M=1 \mid S F, X_{i}, \varepsilon_{i}\right)=\Lambda\left(y^{I M}\right),
$$

where the index is $y^{I M}=\beta_{0}^{I M}+\beta_{1}^{I M} S F_{i}+\beta_{2}^{I M} X_{i}+\varepsilon_{i}^{I M}$. The indices includes a vector of individual characteristics $X$ (including a constant), a dummy for the probability of being intermarried ( $I M$ ) in equation (1) and an unobserved heterogeneity random effect denoted as $\varepsilon_{i}^{S E}$ and $\varepsilon_{i}^{I M}$, respectively.

To make such estimation feasible, we instrument our intermarried indicator with the share of female migrants (denoted by $S F$ ) in the state at the time the migrant arrived in the US. The higher the share of female migrants in the state at that time, the less likely it should be for a migrant to be intermarried (Bisin and Verdier, 2000, provide empirical support to this notion). The main identification assumption is that controlling for the current share of co-ethnics in the state, the share of females at the time of migration does not affect the decision to enter self-employment in the current period.

The joint likelihood for each individual can be written as:

$$
L_{i}^{p}=\left(\Lambda(\cdot)^{y^{S E}}(1-\Lambda(\cdot))^{\left(1-y^{S E}\right)}\right)\left(\Lambda(\cdot)^{y^{I M}}(1-\Lambda(\cdot))^{\left(1-y^{I M}\right)}\right)
$$

where the likelihood contributions are defined in (1) and (2). The unobserved heterogeneity distribution $G\left(\varepsilon^{S E}, \varepsilon^{I M}\right)$ is defined flexibly as a discrete distribution with support points denoted by $\varepsilon_{p}^{j}$, for $j=S E, I M$, and the corresponding probability mass given by $\operatorname{Pr}\left(\varepsilon^{j}=\varepsilon_{p}^{j}\right)=\pi_{p}$, where $p=1, . ., P$ denotes the support points. This approach in modeling unobserved heterogeneity is used frequently in labor economics and originates from Heckman and Singer (1984). Each unobserved factor is assumed to be time-invariant and individual specific, and it is allowed to be correlated across 
transitions. For identification purposes, since we include a constant in the vector $X$, we normalize one of the mass points of each discrete random effect to zero.

The sample log-likelihood can be written as follows:

$$
\log L=\sum_{p=1}^{P} \pi_{p} \log L_{i}^{p},
$$

where $L_{i}^{p}$ is defined as in (3).

Table 4 presents results from the first equation that models the probability of being intermarried. We employ the same sample of immigrants used to model entry into entrepreneurship. Once again, we present results from the full sample and from the subsamples of immigrants who arrived at different ages or married after migration. Our instrument always displays the expected sign, and it is precisely estimated for the subsamples of immigrants who were younger than 20 years when they arrived in the US or married after migration. Intuitively for these groups, the higher the share of female migrants in the state when they arrived in the country, the lower the probability is of being intermarried.

[Table 4 about here]

In Table 5, we present results from the joint estimation which take into account the endogeneity of being intermarried with reference to the aforementioned groups for which our instrument is valid. For completeness, columns 1 and 3 present the estimates from the first stage regression, while columns 2 and 4 show the estimates from the main equation of interest. The effect of being intermarried is negative and statistically significant, and it seems to be downward biased in the case in which the probability of intermarriage is assumed to be exogenous. This can be seen from the comparison of the 
estimated effects between columns 3 and 4 of Table 3 with the respective ones in columns 3 and 4 of Table 5, with the latter being stronger. The unobserved heterogeneity distribution reported at the bottom of Table 5 suggests that there is a large share in the sample (more than 90 percent) which, due to unobservables, exhibits a higher probability of being intermarried and a lower probability of entering into selfemployment. There is a smaller second group which exhibits a lower probability to be intermarried and a much higher probability to start up a business.

[Table 5 about here]

All in all, our key finding on the negative influence of being intermarried on transitions into entrepreneurship is robust when we take into account the fact that unobserved characteristics affect both business ownership and the probability of being married to a native. In fact, our results suggest that when such correlation is not taken into account, the effect of being intermarried tends to be downwards biased.

\subsection{Transitions out of Entrepreneurship}

Having studied in detail the role of intermarriage in transitions into entrepreneurship, we also examine its relevance for transitions out of entrepreneurship. To this end, we estimate a discrete-time duration model on business survival that takes into account left truncation and right censoring in the data. The former issue relates to the fact that the stock of entrepreneurs initially observed has on average lower risk of exiting from entrepreneurship, forming a selected group of immigrants that is dominated by those successful enough to survive up to that point. ${ }^{6}$ Ignoring such a selection mechanism

\footnotetext{
${ }^{6}$ We are able to take into account left censoring given that the data provide information on the exact starting date of each particular business.
} 
might lead to biased inference. The latter issue refers to the inability of observing the exit time in the data for some spells. More details on the model set up and an application of survival in entrepreneurship of immigrants to the US and their descendants can be found in Georgarakos and Tatsiramos (2009).

As discussed in Section 2, the sample comprises of immigrants who run their own business. Results from this model are presented in Table 6 both for the full sample under examination and for those younger than 35 years when they arrived at the host country. $^{7}$

For those who run their own business, being married to a native spouse significantly reduces the probability of exiting from entrepreneurship. This suggests that entrepreneurs who are intermarried have better survival probabilities. The results from the estimation using the sample of immigrants that were younger than 35 years when they first came to the US suggest a similar result, although the estimates are less precise due to the sample size drop. All in all, our results point to an interesting asymmetry: on the one hand, being intermarried reduces the chance of starting up a business possibly because better access to local networks can help transitions into other forms of employment (e.g. paid employment). On the other hand, once the decision to set up a business has been made, superior access to local networks through marriage to a native facilitates business survival. ${ }^{8}$

\section{[Table 6 about here]}

\footnotetext{
${ }^{7}$ Due to sample size constraints we could not estimate the model for the sample of immigrants who arrived at the host country less than 20 years old and for those married after migration.

8 We attempted to estimate jointly the probability of being intermarried and the survival into entrepreneurship using a similar estimation method to the one used for the entry decision. We have failed, however, to identify significant unobserved heterogeneity in our sample, so we only present the independent transitions in Table 6.
} 


\section{Conclusion}

In this paper, we examine the extent to which the transition of male immigrants into and out of entrepreneurship is affected by the immigrant status of their spouse. Using US survey data from the SIPP, we find that the immigrant status of the spouse and the implied access to different types of networks (dominated by natives or immigrants) has asymmetric implications for transitions in entrepreneurship. On the one hand, immigrants who are married to a native are significantly less likely to enter into selfemployment compared to those married to an immigrant. This finding is proven robust when we take into account the possibility in our estimation that unobserved factors affect both the probability of entering into entrepreneurship and being intermarried. On the other hand, immigrants with a native spouse are significantly less likely to exit from entrepreneurship compared to their counterparts married to an immigrant.

Our analysis yields insights on how access to different types of networks among otherwise similar immigrants - can influence their employment choices and especially transitions regarding entrepreneurship. Moreover, our results imply that for immigrants who use self-employment as a pathway from unemployment or inactivity to paid employment in the wage sector, the limited access to information that could ease job search is likely to direct them into self-employment, whereas access to such information may have allowed them to enter into paid-employment directly.

These findings contribute to our understanding of immigrants' transitions in and out of entrepreneurship and can be of interest to policy makers who design policies which aim to assist immigrants to improve their well-being and to integrate faster in the host country. The significant role of intermarriage in business transitions implies that there is room for promoting policies that will assist the less integrated immigrants to overcome information barriers related to job search and employment opportunities. 
Facilitating better access to information for these groups can help those immigrants who use self-employment as a stepping stone to paid employment find a job in the wage sector directly. In addition, it can increase the survival probability in entrepreneurship of those immigrants who run their own business. The latter can be particularly relevant for the less well-to-do given that entrepreneurship has been generally shown to offer an avenue to escape poverty for the most disadvantaged groups of households. ${ }^{9}$

\footnotetext{
${ }^{9}$ See for instance, Hotz-Eakin, Rosen and Weathers (2000), who present evidence of stronger upward mobility in the income distribution among low-income self-employed workers compared to low-income wage/salary workers, and Fairlie (2004), who documents faster earnings-growth for the former group.
} 


\section{References}

Beaman, L. A. (2008). Social Networks and the Dynamics of Labor Market Outcomes: Evidence from Refugees, Unpublished manuscript.

Bisin, A., \& Verdier, T. (2000). Beyond the Melting Pot: Cultural Transmission, Marriage, and the Evolution of Ethnic and Religious Traits. Quarterly Journal of Economics, 115(3), 955-988.

Blau, D. M., \& Robins, P. K. (1990). Job Search Outcomes for the Employed and the Unemployed. Journal of Political Economy, 98(3), 637-655.

Borjas, G. J. (1995). Ethnicity, Neighborhoods, and Human Capital Externalities. American Economic Review, 85(3), 365-390.

Calvó Armengol, A. (2004). Job Contact Networks. Journal of Economic Theory, 115(1), 191-206.

Calvó Armengol, A., \& Jackson, M. O. (2007). Networks in Labor Markets: Wage and Employment Dynamics and Inequality. Journal of Economic Theory, 132(1), 27-46.

Chiswick, B. R., \& Houseworth, C. A. (2008). Ethnic Intermarriage among Immigrants: Human Capital and Assortative Mating. IZA Discussion Paper No. 3740.

Cobb-Clark, D. A., \& Hildebrand, V. A. (2006). The Wealth and Asset Holdings of U.S.-Born and Foreign-Born Households: Evidence from SIPP Data. Review of Income and Wealth, 52(1), 17-42.

Cutler, D. M., Glaeser, E. L., \& Vigdor, J. L. (2005). Ghettos and the Transmission of the Ethnic Capital. In: G.C. Loury, T. Moddod \& S. M. Teles (Eds), Ethnicity, Social Mobility and Public Policy: Comparing the US and the UK. Cambridge: Cambridge University Press.

Edin, P.-A., Fredriksson, P., \& Åslund, O. (2003). Ethnic Enclaves and the Economic Success of Immigrants- Evidence from a Natural Experiment. Quarterly Journal of Economics, 118(1), 329-357.

Fairlie, R. W., \& Meyer, B. D. (1996). Ethnic and Racial Self-Employment Differences and Possible Explanations. Journal of Human Resources, 31(4), 757-793.

Fairlie, R. W. (2004). Earnings Growth among Young Less-Educated Business Owners. Industrial Relations, 43(3), 634-659. 
Fairlie, R. W. (2005). Entrepreneurship among Disadvantaged Groups: An Analysis of the Dynamics of Self-Employment by Gender, Race, and Education. In: Parker S. C., Z. J. Acs \& D. R. Audretsch (Eds), Handbook of Entrepreneurship, Volume 2. Dordrecht: Kluwer Academic Publishers (forthcoming).

Furtado, D., \& Theodoropoulos, N. (2009). Intermarriage and Immigrant Employment: The Role of Networks. CReAM DP No. 06/09.

Georgarakos, D., \& Tatsiramos, K. (2009). Entrepreneurship and Survival Dynamics of Immigrants to the U.S. and their Descendants. Labour Economics, 16(2), 161170.

Holtz-Eakin, D., Rosen, H. S., \& Weathers, R. (2000). Horatio Alger Meets the Mobility Tables. Small Business Economics, 14(4), 243-274.

Heckman, J. J., \& Singer, B. (1984). A Method for Minimizing the Impact of Distributional Assumptions in Econometric Models for Duration Data. Econometrica, 52(2), 271-320.

Ioannides, Y., \& Datcher Loury, L. (2004). Job Information Networks, Neighborhood Effects, and Inequality. Journal of Economic Literature, 42(4), 1056-1093.

Meng, X., \& Gregory, R. G. (2005). Intermarriage and the Economic Assimilation of Immigrants. Journal of Labor Economics, 23(1), 135-175.

Munshi, K. (2003). Networks in the Modern Economy: Mexican Migrants in the U.S. Labor Market. Quarterly Journal of Economics, 118(2), 549-579.

Patel, K., \& Vella, F. (2007). Immigrant Networks and Their Implications for Occupational Choice and Wages. IZA Discussion Paper No. 3217. 


\begin{tabular}{|c|c|c|c|c|c|c|}
\hline \multirow[b]{2}{*}{ Variables } & \multicolumn{2}{|c|}{ Full Sample } & \multicolumn{2}{|c|}{$\begin{array}{c}\text { Native-Born } \\
\text { Spouse } \\
\end{array}$} & \multicolumn{2}{|c|}{$\begin{array}{l}\text { Foreign-Born } \\
\text { Spouse } \\
\end{array}$} \\
\hline & Mean & S.D & Mean & S.D & Mean & S.D \\
\hline Native Spouse & 0.225 & 0.418 & 1.000 & 0.000 & 0.000 & 0.000 \\
\hline Naturalized & 0.401 & 0.490 & 0.586 & 0.493 & 0.348 & 0.476 \\
\hline Years since Migration & 16.270 & 9.968 & 21.465 & 11.100 & 14.763 & 9.079 \\
\hline Age & 43.006 & 10.800 & 43.881 & 10.646 & 42.751 & 10.836 \\
\hline High School Drop out & 0.370 & 0.483 & 0.207 & 0.406 & 0.417 & 0.493 \\
\hline High School & 0.222 & 0.416 & 0.252 & 0.435 & 0.213 & 0.410 \\
\hline College beyond High School & 0.205 & 0.404 & 0.263 & 0.441 & 0.189 & 0.391 \\
\hline College Graduate & 0.203 & 0.402 & 0.279 & 0.449 & 0.181 & 0.385 \\
\hline Number of Children & 1.81 & 1.39 & 1.47 & 1.20 & 1.90 & 1.43 \\
\hline State Unemployment Rate & 4.199 & 1.224 & 4.066 & 1.196 & 4.238 & 1.229 \\
\hline Urban Resident & 0.744 & 0.437 & 0.751 & 0.433 & 0.742 & 0.438 \\
\hline Share of Co-Ethnics in State & 0.046 & 0.040 & 0.037 & 0.037 & 0.048 & 0.041 \\
\hline Unemployed & 0.027 & 0.161 & 0.015 & 0.122 & 0.030 & 0.171 \\
\hline Inactive & 0.119 & 0.324 & 0.123 & 0.328 & 0.118 & 0.322 \\
\hline English Speaking Country & 0.082 & 0.274 & 0.197 & 0.398 & 0.048 & 0.214 \\
\hline Europe & 0.187 & 0.390 & 0.337 & 0.474 & 0.143 & 0.351 \\
\hline Canada & 0.033 & 0.177 & 0.105 & 0.307 & 0.012 & 0.107 \\
\hline Australia and New Zealand & 0.010 & 0.100 & 0.010 & 0.099 & 0.010 & 0.101 \\
\hline Mexico & 0.420 & 0.494 & 0.298 & 0.458 & 0.455 & 0.498 \\
\hline Central America & 0.065 & 0.246 & 0.044 & 0.206 & 0.071 & 0.256 \\
\hline South America & 0.067 & 0.251 & 0.070 & 0.256 & 0.067 & 0.249 \\
\hline Caribbean & 0.099 & 0.298 & 0.095 & 0.294 & 0.100 & 0.300 \\
\hline \multirow[t]{2}{*}{ Asia } & 0.120 & 0.325 & 0.040 & 0.197 & 0.143 & 0.350 \\
\hline & \multicolumn{2}{|l|}{ Median } & \multicolumn{2}{|l|}{ Median } & \multicolumn{2}{|l|}{ Median } \\
\hline Wealth & \multicolumn{2}{|l|}{3.389} & \multicolumn{2}{|l|}{8.923} & \multicolumn{2}{|l|}{2.341} \\
\hline Income & \multicolumn{2}{|l|}{0.380} & \multicolumn{2}{|l|}{0.519} & \multicolumn{2}{|l|}{0.347} \\
\hline Number of Individuals & \multicolumn{2}{|c|}{1528} & \multicolumn{2}{|c|}{324} & \multicolumn{2}{|c|}{1204} \\
\hline
\end{tabular}

Source: SIPP 1996, 2001. Wealth and income are measured in 10,000 dollars in 1996 prices. 


\begin{tabular}{|c|c|c|c|c|c|c|}
\hline \multirow[b]{2}{*}{ Variables } & \multicolumn{2}{|c|}{ Full Sample } & \multicolumn{2}{|c|}{$\begin{array}{l}\text { Native-Born } \\
\text { Spouse }\end{array}$} & \multicolumn{2}{|c|}{$\begin{array}{c}\text { Foreign-Born } \\
\text { Spouse } \\
\end{array}$} \\
\hline & Mean & S.D & Mean & S.D & Mean & S.D \\
\hline Native Spouse & 0.213 & 0.410 & 1.000 & 0.000 & 0.000 & 0.000 \\
\hline Naturalized & 0.492 & 0.501 & 0.539 & 0.502 & 0.479 & 0.501 \\
\hline Years since Migration & 18.082 & 9.805 & 21.887 & 9.368 & 17.049 & 9.683 \\
\hline Age & 44.260 & 9.886 & 44.923 & 8.656 & 44.080 & 10.203 \\
\hline High School Drop out & 0.279 & 0.449 & 0.199 & 0.402 & 0.301 & 0.459 \\
\hline High School & 0.260 & 0.439 & 0.315 & 0.468 & 0.245 & 0.431 \\
\hline College beyond High School & 0.210 & 0.408 & 0.230 & 0.424 & 0.204 & 0.404 \\
\hline College Graduate & 0.251 & 0.435 & 0.256 & 0.440 & 0.250 & 0.434 \\
\hline Number of Kids & 1.62 & 1.19 & 1.49 & 1.03 & 1.65 & 1.23 \\
\hline State Unemployment Rate & 5.344 & 1.117 & 5.275 & 1.152 & 5.363 & 1.109 \\
\hline Urban Resident & 0.802 & 0.399 & 0.760 & 0.430 & 0.813 & 0.391 \\
\hline Number of Employees <25 & 0.853 & 0.354 & 0.839 & 0.371 & 0.857 & 0.351 \\
\hline Share of Co-Ethnics in State & 0.036 & 0.031 & 0.031 & 0.024 & 0.037 & 0.032 \\
\hline English Speaking Country & 0.069 & 0.253 & 0.161 & 0.370 & 0.044 & 0.204 \\
\hline Europe & 0.292 & 0.456 & 0.519 & 0.504 & 0.231 & 0.422 \\
\hline Mexico & 0.269 & 0.444 & 0.192 & 0.397 & 0.289 & 0.454 \\
\hline Central America & 0.075 & 0.264 & 0.028 & 0.166 & 0.088 & 0.284 \\
\hline South America & 0.090 & 0.286 & 0.095 & 0.295 & 0.088 & 0.284 \\
\hline Carribean & 0.092 & 0.289 & 0.072 & 0.261 & 0.097 & 0.297 \\
\hline Asia & 0.183 & 0.387 & 0.094 & 0.294 & 0.207 & 0.406 \\
\hline Agriculture & 0.060 & 0.238 & 0.043 & 0.204 & 0.065 & 0.247 \\
\hline Manufacturing & 0.036 & 0.187 & 0.043 & 0.205 & 0.034 & 0.183 \\
\hline Transportation & 0.086 & 0.281 & 0.059 & 0.237 & 0.093 & 0.292 \\
\hline Trade Durables & 0.027 & 0.164 & 0.033 & 0.181 & 0.026 & 0.159 \\
\hline Trade Non-Durables & 0.022 & 0.147 & 0.015 & 0.121 & 0.024 & 0.154 \\
\hline Retail & 0.211 & 0.408 & 0.190 & 0.395 & 0.216 & 0.413 \\
\hline Financial Services & 0.019 & 0.136 & 0.014 & 0.118 & 0.020 & 0.140 \\
\hline Business Services & 0.141 & 0.349 & 0.047 & 0.213 & 0.167 & 0.374 \\
\hline Personal Services & 0.042 & 0.200 & 0.065 & 0.249 & 0.035 & 0.185 \\
\hline Entertainment Services & 0.032 & 0.176 & 0.061 & 0.241 & 0.024 & 0.153 \\
\hline \multirow[t]{2}{*}{ Professional Services } & 0.102 & 0.303 & 0.147 & 0.356 & 0.090 & 0.286 \\
\hline & \multicolumn{2}{|l|}{ Median } & \multicolumn{2}{|l|}{ Median } & \multicolumn{2}{|l|}{ Median } \\
\hline Wealth & \multicolumn{2}{|l|}{9.743} & \multicolumn{2}{|l|}{22.998} & \multicolumn{2}{|l|}{8.173} \\
\hline Income & \multicolumn{2}{|l|}{0.431} & \multicolumn{2}{|l|}{0.507} & \multicolumn{2}{|l|}{0.414} \\
\hline Number of Individuals & \multicolumn{2}{|c|}{324} & \multicolumn{2}{|c|}{65} & \multicolumn{2}{|c|}{259} \\
\hline
\end{tabular}

Source: SIPP 1996, 2001. Wealth and income are measured in 10,000 dollars in 1996 prices. 
Table 3. Transition into Entrepreneurship. Logistic Regression - Dependent Variable: Enter into Business between $\mathrm{t}$ and $\mathrm{t}+1$

Full Sample

\begin{tabular}{|c|c|c|}
\hline All & Age at Migration <35 & Age at Migration $<20$ \\
\hline COEF. S.E & COEF. S.E & COEF. S.E \\
\hline
\end{tabular}

$\frac{\text { Migration }}{\text { All }}$

\section{Native Spouse}

Naturalized

Years since Migration

Years since Migration²

Age

Age $^{2}$

High School

College beyond HS

College Graduate

Number of Children

$\mathrm{HH}$ Wealth

HH Income

State Unem. Rate

Urban Resident

Share of Migrants in State

Previously Unemployed

Previously Inactive

English Speaking Country

Constant

Country of Birth Fixed Effects

Year Dummies

Number of Individuals

Number of Observations

Log-Likelihood
(1)

$-0.6370 .273 * *$

0.1410 .212

0.0410 .039

$\begin{array}{lll}-0.067 & 0.106\end{array}$

0.0140 .077

$\begin{array}{lll}-0.001 & 0.001\end{array}$

$\begin{array}{lll}0.244 & 0.249\end{array}$

$\begin{array}{lll}0.184 & 0.284\end{array}$

0.2480 .295

$\begin{array}{ll}-0.104 & 0.067\end{array}$

0.0120 .014

$-0.1220 .047 * *$

0.0230 .101

$\begin{array}{lll}-0.220 & 0.198\end{array}$

$-0.0520 .036$

$1.8850 .245 * * *$

$1.3190 .243 * * *$

0.2780 .355

-3.1191 .664 *

YES

YES

1,528

12,637

$-798.50$
(2)

$\begin{array}{lll}-0.736 & 0.288 * *\end{array}$

$\begin{array}{lll}0.180 & 0.227\end{array}$

$\begin{array}{lll}0.067 & 0.045\end{array}$

$\begin{array}{lll}-0.120 & 0.122\end{array}$

$\begin{array}{lll}-0.010 & 0.085\end{array}$

0.0000 .001

0.0660 .273

$\begin{array}{ll}-0.092 & 0.312\end{array}$

0.1540 .328

$\begin{array}{lll}-0.101 & 0.072\end{array}$

0.0090 .015

$-0.1410 .054 * *$

0.0650 .112

$\begin{array}{lll}-0.330 & 0.215\end{array}$

$\begin{array}{lll}-0.060 & 0.038\end{array}$

$1.7480 .272 * * *$

$1.0270 .275 * * *$

0.3530 .379

$-2.7641 .792$

YES

YES

1,252

10,180

$-675.57$
(3)

$-0.8860 .404 * *$

0.2860 .448

0.0320 .117

0.1430 .273

$\begin{array}{lll}-0.297 & 0.204\end{array}$

0.0020 .003

$-0.2500 .514$

$-0.6730 .654$

$-0.4290 .662$

0.0140 .123

0.0200 .026

$-0.0300 .088$

0.1350 .159

$-0.2450 .349$

$-0.0730 .064$

$1.8640 .444 * * *$

1.3130 .505 **

0.9120 .699

1.5933 .559

YES

YES

543

3,831

$-245.00$
(4)

$-0.8290 .327 * *$

0.1620 .262

$-0.0070 .057$

0.0640 .144

0.0620 .104

$\begin{array}{lll}-0.001 & 0.001\end{array}$

0.2360 .312

$\begin{array}{lll}-0.243 & 0.381\end{array}$

0.0460 .393

$\begin{array}{lll}-0.072 & 0.089\end{array}$

0.0020 .017

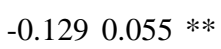

0.0330 .140

$\begin{array}{ll}-0.229 & 0.250\end{array}$

$-0.0620 .045$

$1.9100 .305 * * *$

$1.2810 .327 * * *$

0.4930 .448

$-3.6542 .172 *$

YES

YES

899

7,703

$-493.53$

Notes: $* * *, * *, *$ denote significance at $1 \%, 5 \%, 10 \%$, respectively. 


\begin{tabular}{ll}
\hline All \\
\hline COEF. & S.E
\end{tabular}

All
COEF

$$
\text { (2) }
$$

Share of Females

Naturalized

Years since Migration

Years since Migration ${ }^{2}$

Age

Age $^{2}$

High School

College beyond HS

College Graduate

Number of Children

HH Wealth

HH Income

State Unem. Rate

Urban Resident

Previously Unemployed

Previously Inactive

English Speaking Country

Constant

Country of Birth Fixed Effects

Year Dummies

Number of Individuals

(1)

$-0.0870 .011 * * *$

$-0.0180 .017$

$0.3140 .177 *$

$-0.0030 .035$

$0.2080 .083 * *$

0.0710 .058

$-0.0020 .001 * *$

$0.4670 .218 * *$

0.3540 .237

$0.4810 .258 *$

$-0.1480 .065 * *$

$0.0200 .011 *$

0.0020 .068

$-0.2820 .086 * * *$

$-0.0250 .177$

$-0.5150 .531$

$\begin{array}{lll}-0.029 & 0.258\end{array}$

0.7170 .275 **

$-0.5310 .112 * * *$

0.5331 .373

NO

NO

Log-Likelihood

Notes: $* * *, * *, *$ denote significance at $1 \%, 5 \%, 10 \%$, respectively.

\section{Full Sample}

Age at Migration $<35 \quad$ Age at Migration $<20$

COEF. S.E COEF. S.E

(3)

(4)

$-0.0330 .020$

$0.4070 .194 * *$

$-0.0050 .042$

$0.2210 .096 * *$

0.0390 .065

$-0.0010 .001$

$0.5350 .235 * *$

0.3870 .254

$0.5680 .286 * *$

$-0.1160 .072$

0.0160 .012

0.0030 .074

$-0.2890 .093 * * *$

0.0280 .191

$-0.8480 .654$

$\begin{array}{lll}0.057 & 0.287\end{array}$

0.6130 .310 **

0.9151 .486

YES

YES

1,217

$-504.88$

$-0.1110 .045 * *$

0.3740 .301

$\begin{array}{lll}-0.020 & 0.098\end{array}$

$\begin{array}{lll}0.248 & 0.213\end{array}$

$-0.2030 .159$

0.0020 .002

$0.6190 .368 *$

$-0.0350 .430$

$\begin{array}{lll}-0.060 & 0.485\end{array}$

0.0150 .110

0.0260 .018

0.4530 .211 **

$\begin{array}{lll}-0.075 & 0.138\end{array}$

$-0.2630 .301$

$-1.0811 .186$

$-0.1140 .584$

0.3580 .525

$-0.3523 .108$

YES

YES

456

$-209.36$
Married After Migration

\begin{tabular}{ll}
\hline & All \\
\hline COEF. & S.E
\end{tabular}

(5)

$-0.0540 .023 * *$

$0.3660 .214 *$

$\begin{array}{ll}-0.040 & 0.049\end{array}$

$0.244 \quad 0.109 * *$

$-0.037 \quad 0.076$

$\begin{array}{ll}0.000 & 0.001\end{array}$

$0.608 \quad 0.256$ **

$0.5770 .280 * *$

$0.640 \quad 0.318 * *$

$-0.170 \quad 0.081 * *$

$0.010 \quad 0.013$

$0.017 \quad 0.084$

$-0.2050 .100 * *$

$-0.1390 .205$

$-2.0541 .059 *$

$\begin{array}{ll}0.071 & 0.334\end{array}$

$0.409 \quad 0.345$

$2.368 \quad 1.657$

YES

YES

899

$-407.75$ 
Table 5. Joint Estimation of Having a Native Spouse and Entry into Entrepreneurship.

Age at Migration $<\mathbf{2 0}$

COEF. S.E

Share of Females

Native Spouse

Naturalized

Years since Migration

Years since Migration ${ }^{2}$

Age

Age $^{2}$

High School

College beyond HS

College Graduate

Number of Children

HH Wealth

HH Income

State Unem. Rate

Urban Resident

Share of Migrants in State

Previously Unemployed

Previously Inactive

English Speaking Country

Mass Point 1

Mass Point 2

P1

P2

Country of Birth Fixed Effects

Year Dummies

Number of Individuals

Number of Observations

Log-Likelihood/N
(1)

COEF. S.E

(2)

$-0.1110 .045 * *$

0.3730 .301

$-0.0200 .098$

0.2480 .213

$-0.2020 .162$

0.0020 .002

0.6160 .369 *

$-0.0350 .431$

$-0.0650 .486$

0.0140 .110

0.0260 .018

0.4520 .211 **

$\begin{array}{lll}-0.077 & 0.138\end{array}$

$-0.2650 .301$

$-1.0871 .187$

$-0.1100 .585$

0.3600 .526

$-0.3373 .126$

$-0.1270 .598$

YES

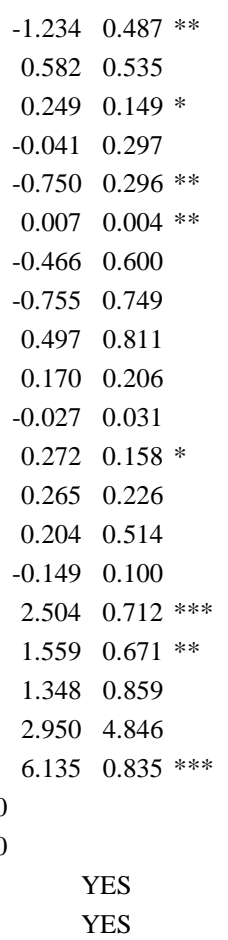

Married After Migration

\begin{tabular}{llll}
\hline COEF. S.E & COEF. & S.E
\end{tabular}

(3)

-0.0540 .023 **

$\begin{array}{llll}0.368 & 0.215 * & -0.038 & 0.321\end{array}$

$\begin{array}{lllll}-0.040 & 0.049 & 0.041 & 0.065\end{array}$

$\begin{array}{llll}0.245 & 0.109 * * & -0.041 & 0.159\end{array}$

$\begin{array}{llll}-0.037 & 0.077 & 0.148 & 0.108\end{array}$

$\begin{array}{llll}0.000 & 0.001 & -0.002 & 0.001\end{array}$ *

$\begin{array}{llll}0.605 & 0.257 * * & 0.558 & 0.367\end{array}$

$\begin{array}{llll}0.577 & 0.280 * * & -0.368 & 0.502\end{array}$

$\begin{array}{lllll}0.637 & 0.319 * * & 0.335 & 0.480\end{array}$

$\begin{array}{llll}-0.169 & 0.081 * * & -0.151 & 0.117\end{array}$

$\begin{array}{llll}0.010 & 0.013 & 0.002 & 0.018\end{array}$

$\begin{array}{lllll}0.017 & 0.084 & -0.165 & 0.062 * * *\end{array}$

$\begin{array}{llll}-0.205 & 0.100 * * & 0.085 & 0.148\end{array}$

$\begin{array}{llll}-0.141 & 0.205 & -0.259 & 0.296\end{array}$

$-0.054 \quad 0.060$

$\begin{array}{ll}2.336 & 0.354 * * *\end{array}$

$\begin{array}{ll}1.301 & 0.374 * * *\end{array}$

$0.238 \quad 0.514$

$-5.7792 .636 * *$

$5.9130 .545 * * *$

$-0.122 \quad 0.702$

0.973

0.027

YES

YES

889

7,703

$-65.42$

Notes: ***, **,* denote significance at $1 \%, 5 \%, 10 \%$, respectively. The first column for each estimation refers to the estimation of the probability of being married to a native. The second column refers to the probability of entering into business from $\mathrm{t}$ to $\mathrm{t}+1$ measured in quarters. 
Table 6. Discrete-Time Duration Model for the Transition out of Entrepreneurship.

$\frac{\text { All }}{\text { COEF. S.E }} \frac{\text { Age at Migration }<35}{\text { COEF. S.E }}$

(1)

Native Spouse

$-0.8100 .397 * * \quad-0.7610 .425 *$

Naturalized

$\begin{array}{llll}0.148 & 0.300 & 0.260 & 0.322\end{array}$

Years since Migration

$\begin{array}{llll}-0.091 & 0.060 & -0.060 & 0.081\end{array}$

Years since Migration ${ }^{2}$

$0.2650 .151 * \quad 0.2420 .203$

Age

Age $^{2}$

$0.0000 .106 \quad-0.0600 .130$

$\begin{array}{llll}-0.022 & 0.122 & 0.026 & 0.153\end{array}$

High School

$-0.9730 .434 * * \quad-0.9210 .438 * *$

College beyond HS

$\begin{array}{llll}-0.080 & 0.343 & -0.389 & 0.369\end{array}$

College Graduate

$\begin{array}{llll}-0.336 & 0.437 & -0.408 & 0.489\end{array}$

Number of Children

$-0.1710 .110$

$-0.1440 .119$

HH Wealth

$\begin{array}{llll}-0.017 & 0.013 & -0.019 & 0.014\end{array}$

$\mathrm{HH}$ Income

$-0.0420 .063$

$-0.0190 .075$

State Unem. Rate

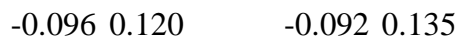

Urban Resident

$\begin{array}{llll}-0.068 & 0.280 & -0.211 & 0.330\end{array}$

Number of Employees <25

$\begin{array}{llll}-0.752 & 0.308 * * & -0.630 & 0.348 *\end{array}$

Share of Migrants in State

$0.1120 .065 * \quad 0.1440 .079 *$

English Speaking Country

0.7820 .648

0.8220 .700

Constant

$-0.9672 .255$

$-0.3282 .646$

Country of Birth Fixed Effects

Duration Dependence Dummies

YES

YES

Year Dummies

YES YES

Number of Individuals

YES

YES

324

268

Number of Observations

9,264

7,844

Log-Likelihood

$-459.57$

$-379.55$

Notes: $* * *, * *, *$ denote significance at $1 \%, 5 \%, 10 \%$, respectively. 